\title{
Synthesis, Spectroscopic Characterization, Electrochemical Properties and Biological Activity of 1-[(4Hydroxyanilino)- methylidene] naphthalen-2(1H)-one and its Mn (III) Complex
}

\author{
Safia Chahmana ${ }^{1}$, Saida Keraghel ${ }^{1}$, Fatiha Benghanem $^{1, *}$, R. Ruíz-Rosas $^{2}$, Ali Ourari $^{1}$, E. Morallón $^{2}$ \\ ${ }^{1}$ Laboratoire d'Electrochimie, d'Ingénierie Moléculaire et de Catalyse Rédox, \\ Département de Génie des Procédés, Faculté de Technologie, Université Ferhat \\ Abbas Sétif 1, Algérie. \\ ${ }^{2}$ Instituto Universitario de Materiales, Universidadde Alicante, Ap. 99. E-03080 Alicante, ESPAÑA \\ *E-mail: benghanem_f@yahoo.fr
}

doi: $10.20964 / 2018.01 .27$

Received: 12 September 2017 / Accepted: 29 October 2017 / Online Published: 1 December 2017

\begin{abstract}
The bidentate (HL) Schiff base was synthesized by reacting 2-hydroxy-1-naphthaldehyde with 4aminophenol in absolute ethanol. The resulting HL ligand was also coordinated with the manganese ions to obtain $\mathrm{Mn}(\mathrm{III})$ complex $\left[\mathrm{Mn}(\mathrm{III}) \mathrm{L}_{2} \mathrm{ClPy}\right.$ (Py=pyridine)]. This Schiff base and its manganese(III) complex were characterized by multiple and usual methods including the ${ }^{1} \mathrm{H}$ NMR, ${ }^{13} \mathrm{C}$ NMR, elemental analysis (EA), FT-IR, UV-Vis, mass spectroscopy (MS), XRD, XPS and cyclic voltametry $(\mathrm{CV})$. It was found that the ligand acts as a bidentate chelate. It coordinates with azomethine nitrogen and phenoxide oxygen. The other coordination sites, they are occupied by a chloride anion and a pyridine molecule completing the formation of $\mathrm{Mn}$ (III) Schiff base complex which is symbolized as $\mathrm{Mn}(\mathrm{III}) \mathrm{L}_{2} \mathrm{ClPy}$. Conductance values measured indicate that these compounds do not possess an electrolytic character. The electrochemical behavior of the (HL) ligand and its manganese(III) complex have been investigated using a glassy carbon electrode in the presence of

$0.1 \mathrm{M} \mathrm{Bu}_{4} \mathrm{NClO}_{4}$ solution as a supporting electrolyte in dimethylformamide (DMF) solution. The redox system of manganese(III) complex seems to be consistent with a quasi-reversible system involving a mono electronic transfer $\left(\mathrm{Mn}^{\mathrm{III}} / \mathrm{Mn}^{\mathrm{II}}\right)$. Both compounds, HL ligand and its $\mathrm{Mn}$ (III) complex were as well tested in biological activity. The obtained results indicate that they exhibit no antifungal activity but have moderate antibacterial activity towards the same organism studied. Also it is noted that this compounds have high DPPH radical-scavenging activity.
\end{abstract}

Keywords: Bidentate Schiff base ligand, Manganese(III) complex, X-Ray Analysis, XPS-analysis, Cyclic voltammetry, Biological activity.

\section{FULL TEXT}


(C) 2018 The Authors. Published by ESG (www.electrochemsci.org). This article is an open access article distributed under the terms and conditions of the Creative Commons Attribution license (http://creativecommons.org/licenses/by/4.0/). 